\title{
LOS HALLAZGOS DEL SACROMONTE A LA LUZ DE LA HISTORIA DE LA IGLESIA Y DE LA TEOLOGÍA CATÓLICA
}

\author{
Francisco JAVIER Martínez MEdina \\ Universidad de Granada
}

Pocas de las múltiples invenciones que tuvieron lugar en la España del Quinientos han sido tan estudiadas como los hallazgos del Sacromonte granadino. Desde que en aquel 18 de marzo de 1588 tuviera lugar el primer hallazgo al derribar la torre de la mezquita de Granada o torre Turpiana, los escritos y la investigación en torno a los hechos -no es el momento ni el lugar de recordarlos por ser de sobra conocidos por los especialistas en estos temas - han sido abundantes y constantes. En los últimos años una serie de circunstancias han contribuido nuevamente a poner el tema de actualidad, aunque no siempre se lo ha tratado con el mismo acierto. En las últimas décadas del pasado siglo inicié un campo de investigación histórica sobre los hallazgos como origen de la fundación de la Abadía del Sacromonte, estudiándolos en sus fuentes originales y en su contexto histórico. En 1995, fecha en que se conmemoró el IV Centenario de los primeros hallazgos ${ }^{1}$, trabajé para conseguir recuperar este legado histórico y lo que ha generado a lo largo del tiempo, pero circunstancias que no vienen al caso lo impidieron. El pasado año 2000 se me concedió el privilegio, como historiador y como granadino, de poder exponer públicamente - y por primera vez desde que fueron enviados a Roma- los libros plúmbeos y el pergamino encontrado en la Torre Turpiana, junto a las láminas martiriales que se guardaban en la Abadía sacromontana, con motivo de la exposición que comisarié en la Catedral en conmemoración del Año Jubilar y del V Centenario del Emperador Carlos ${ }^{2}$.

${ }^{1}$ Cfr. Martínez Medina, F.J., "El Sacromonte de Granada y los sacromontes: mito y realidad", Proyección, 44 (1997), 3-22; id., "El Sacromonte, símbolo de una época", en Veinte siglos de la Historia de Granada, Granada, 2000, 83-94.

2 Cfr. Martínez Medina, F.J., "Los Libros Plúmbeos del Sacromonte de Granada", en Jesucristo y el Emperador Cristiano. Catálogo de la Exposición celebrada en la Cate-

Al-Qanțara XXIII, 2 (2002) 437-475 
Los hallazgos, que tuvieron lugar fundamentalmente en la colina de Valparaíso a finales del siglo XVI, representan un capítulo importante en la historia de la España moderna. Su riqueza de matices es tan variopinta que no se puede, ni creo que se deba, absolutizar ni imponer ninguna línea de investigación como única. Esta riqueza no es otra que la que caracterizó la compleja, difícil y plural sociedad y cultura española de aquel tiempo. De ahí que, teniendo en cuenta las importantísimas investigaciones llevadas a cabo sobre el tema desde diversos campos a lo largo de la historia, sigo un camino no del todo nuevo, pero con variantes significativas en relación a los anteriores trabajos de similar enfoque. Me refiero en concreto a un estudio que nos conduzca en lo posible a la comprensión de los hallazgos sacromontanos desde la óptica de la Historia de la Iglesia en la España moderna y de su pensamiento teológico.

A partir de mis primeras tomas de contacto con el tema, aunque llegaba a parecidas conclusiones que los investigadores que me habían precedido, comprobé lo complejo de su problemática, y sentí la necesidad de buscar nuevos caminos o abordar las fuentes desde otras perspectivas ${ }^{3}$. Esto último es lo que acometí en un segundo estadio de mi investigación en el que, utilizando como fuente fundamental el contenido ideológico-conceptual de los textos plúmbeos, hice una lectura de ellos desde la teología y la problemática doctrinal católica imperante en aquel contexto histórico, para compararla después con el pensamiento y la teología coránica. La riqueza de matices - nuevos unos y con enfoque distinto otros-, que esta lectura ofreció abría alentadores y novedosos caminos a la investigación.

La relación que unos libros establecen con otros confiere a su contenido una mayor credibilidad, a la vez que testimonia una complicada elaboración sistemático-teológica. Concebidos como un gran ciclo temático con desarrollo argumental, en su contenido se expone una complejísima sistemática teológico-doctrinal. No en vano se basan en supuestas revelaciones de la Virgen y de Santiago, y se autoatribuía

dral de Granada con motivo del Año Jubilar y del V Centenario del Emperador Carlos, edición a cargo de F.J. Martínez Medina, Córdoba, CajaSur, 2000, 619-644.

3 Cfr. Martínez Medina, F.J., "El Sacromonte de Granada, un intento de reinculturación entre la guerra de los moriscos y su definitiva expulsión", Chronica Nova, 25 (1998), 349-379. 
su autoría a dos hermanos de raza árabe, san Cecilio y san Tesifón, ambos discípulos del Apóstol y curados por el mismo Jesucristo. Sus intrincados conceptos, que incluyen manifiestas influencias evangélicas y coránicas, defienden complicadísimas tesis e ideas teológicas a modo de síntesis entre el cristianismo y el islam ${ }^{4}$.

El conjunto de los textos, que se consideraban revelados, insistían principalmente en algunos aspectos devocionales y temas fronterizos entre la religiosidad popular cristiana y la musulmana, de profunda raigambre y de especial interés en aquel tiempo y lugar. Entre los personajes que se presentan como centros de interés de los hallazgos destacan tres: Santiago, san Cecilio y la Virgen María. Eran algunas de las piezas esenciales en el proyecto de los inventores, de aquéllos que idearon tan complejo proyecto. A modo de ejemplo del trabajo realizado voy a aplicar esta metodología de estudio, de forma indicativa, a los tres protagonistas.

\section{El Santiago de los textos plúmbeos}

En los textos encontrados, la figura de Santiago ocupa un lugar tan principal que podrían definirse casi como una biografía del Apóstol, sobre todo aquellos pasajes de su vida concernientes a su misión evangelizadora y a su predicación en España. Las láminas de plomo que aparecieron junto a los restos de las reliquias martiriales son las primeras en mencionarlo. El 20 de marzo de 1595, se encontró la lámina que daba noticia del martirio en tiempos de Nerón de san Hiscio, del que se decía fue "discípulo del apóstol Santiago". En las otras dos láminas que aparecieron el 3 y el 30 de abril, correspondientes a los martirios de san Tesifón y de san Cecilio, también se decía que ambos habían sido discípulos de Santiago.

Esta noticia no dejaba de ser original. No sólo por localizar en Granada el martirio de estos tres Varones Apostólicos de las tradiciones medievales, sino también por vincularlos con el apóstol Santiago $\mathrm{y}$, por ende, con la otra tradición medieval de su venida a España,

${ }^{4}$ Cfr. Cabanelas, D., "El Sacromonte, punto de confluencia doctrinal entre Islam y la Cristiandad", en La Abadia del Sacromonte. Exposición artístico-documental. Estudios sobre su significación y origenes, Granada, 1974, 34-40; id., "Un intento de sincretismo islamo-cristiano: Los libros plúmbeos de Granada", en II Congreso Internacional de Estudios sobre las culturas del Mediterráneo Occidental, Barcelona, 1978, 131-142. 
tema que contaba con defensores y detractores en la historiografia hispana moderna.

Pero será en los escritos plúmbeos donde la figura de Santiago adquiere rango de protagonista principal en los hallazgos de la colina de Valparaíso. En todos ellos sus supuestos autores, Cecilio y Tesifón, se denominan discípulos de Jacobo apóstol, que es también quien les revela varios de ellos. Otros se desarrollan como un coloquio entre la Virgen y Santiago. Desatacan asimismo los textos que tienen a Santiago como personaje central y que nos relatan aspectos concretos de su misión apostólica o ponen en su boca aspectos doctrinales. Son éstos los casos de la Oración y defensorio de Santiago, el Ritual de la misa de Santiago, el Libro de la predicación de Santiago apóstol - llamado también Catecismo mayor-, y De los grandes misterios que vio Santiago en el Monte Santo. Por último, dos de los libros plúmbeos - en concreto la Parte primera de los hechos del Apóstol Santiago y la Segunda parte de los hechos del Apóstol Santiago- se dedican a la vida del Apóstol, destacando como dato curioso que son los aparecidos en último lugar y entregados, tras laboriosas gestiones, primero a Felipe III y después al arzobispo Castro en 1607.

Al comienzo de los libros dedicados al Apóstol se da su descripción física. A partir de ella los libros plúmbeos, después de enumerar algunas de la muchas virtudes que lo adornaban y destacar su determinación de dedicarse por entero a predicar y defender el Evangelio, narran los acontecimientos principales de la vida del Apóstol en relación con España. La historia comienza con la visita de Santiago junto a los demás apóstoles a la casa de la "Santa Virgen María" en Ramatha, donde la Señora, en diálogo con Pedro, les habló sobre la Verdad del Evangelio, que no era otra cosa que la quintaesencia del mismo, oculta entonces y que debería manifestarse por mano de las más excelentes de la criaturas de Dios, que en palabras de la Virgen eran "los árabes y su lengua", nación y lengua más excelentes, elegidas ambas por Dios para victoria de su ley, del Evangelio y de su Iglesia en los tiempos futuros. Además, la Señora había recibido el encargo divino de guardar en el extremo de la tierra esta Verdad del Evangelio para que pudiera ser transmitida a las generaciones venideras.

Terminado el discurso, tomó la Virgen en sus manos las tablas que contenían el texto de la Verdad del Evangelio, y se encaminó con los apóstoles en la oscuridad de la noche hacia el monte de los Olivos, "y 
abrióse el monte y encerró las tablas en sus entrañas" ${ }^{5}$. De vuelta todos a la casa, la Virgen envió a Santiago a España con una copia del libro que acababan de enterrar, encomendándole que hiciera lo mismo en estas tierras en el lugar donde resucitase un muerto, y una vez realizado el encargo predicara hasta que se convirtiera un varón. El Apóstol, siguiendo el encargo de la Señora, se puso en camino con sus discípulos Torcuato, Segundo, Hiscio, Eufrasio, y los hermanos Cecilio y Thesiphón.

Una vez en la costa de Palestina embarcan de noche en un navío de salvación y, una vez a bordo, se dirigen a Occidente, hacia Hispania, arribando a la parte oriental de estas tierras, al suroeste español. Después del desembarco, dirigen sus pasos hacia Acci - la actual Guadix - ciudad habitada por romanos y donde nuestros personajes se detienen para comer. La siguiente parada es Ilípula, supuesta ciudad ubicada según sus inventores en el lugar de los hallazgos; junto a la ciudad sitúan el río Dauro o "de oro", el Darro granadino, nombre derivado de la abundancia de oro en sus aguas. Desde aquí suben a un monte de laderas cubiertas de huertas y árboles. Una vez en la cumbre, Santiago pone en el suelo las láminas de plomo que componían el libro que llevaba en la mano. Acto seguido, y tras un temblor de tierra, un hombre sale de su sepulcro, se pone en pie ante el grupo y mantiene un extraño diálogo con el Apóstol. Todo lo cual responde a lo que le había profetizado la Virgen cuando lo envió a España ${ }^{6}$. Santiago entierra allí mismo el libro de la Verdad, y volviendo la vista ve una larga caverna en la que habita con sus discípulos durante cuarenta

\footnotetext{
5 Para el estudio del contenido doctrinal de los libros plúmbeos, hemos utilizado el manuscrito de la traducción que de ellos hizo el Marqués de Estepa existente en el Archivo del Sacromonte, que lleva por título "Versión del Arave Salomónico a el Castellano de los veinte y dos Libros de Plomo descubiertos en el Monte Valparaiso de Granada desde el año de 1595 y del Pergamino de la Torre en el 1588. Fecha. Por el Excmo. Sor. Marquez de Estepa Dn. Adam Centurión, con la ayuda del Licdo. Sergio Maronita sacerdote del Monte Libano, nacido en el Oriente: y de Juan Bapta. Centurión, nacido en el idioma Arave Occidental. Esta versión la hizo el Marques, a el tiempo, o después, que en el año de 1631 hizo la primera versión latina. Esta de su puño; y firmadas todas las ojas de su mano."

En orden a facilitar la comprobación de los distintos textos a que nos referimos, citamos la versión sobre la aludida traducción de M.J. Hagerty, Los libros Plúmbeos del Sacromonte, Madrid, 1980. El primer texto que aquí citamos corresponde al Libro de las acciones de Jacobo Apóstol y de sus milagros, en id., p. 208.

${ }^{6}$ Debe destacarse que estos escritos que implícitamente se datan en el siglo I hablan de España, concepto que se acuñará a raíz de la creación del Estado moderno.
} 
días, mientras escribía la Historia de la Verdad del Evangelio, para que en los tiempos venideros se conociera todo lo referente a la predicación y declaración de la ley.

Mientras tanto envió el Apóstol a la ciudad cercana a uno de sus discípulos para adquirir provisiones y para que se informara sobre sus costumbres y habitantes. Cecilio, el encargado de esta misión, entrando por la puerta oriental vio sus fortalezas y tomó cuentas de los cultos paganos de sus habitantes. Mandó de nuevo Santiago a los discípulos para que entraran por otras puertas, y realiza en la falda del monte un milagro de luz ante el asombro de sus habitantes. Éste y otros milagros causaron la maravilla de las gentes, pero no su conversión. Jacobo comenzó la predicación durante muchos días en la ciudad sin conseguir mover el corazón de las gentes, llorando el Apóstol y sus discípulos ante la dureza de los gentiles. Mientras, componía en aquel lugar del monte la Historia de la Verdad del Evangelio, uno de los libros plúmbeos.

A partir de este momento, el resto del Libro de las acciones de Jacobo Apóstol y de sus milagros se dedica a narrar su largo periplo evangelizador por varias ciudades de las tierras de España como Mentesa, Tolemón, Ciudad de la Puente, Iberia junto al río Ebro, Córdoba a la ribera del río Betis, etc. Se intercalan unos largos y complejos monólogos y diálogos del Apóstol de densa e incomprensible doctrina teológica donde se mezclan los más variados temas, no pocas veces de incomprensible adscripción ideológica. En alguno de estos pasajes se puede establecer un cierto paralelismo entre el contenido de la predicación y algunos de los acontecimientos narrados, con las predicaciones y milagros obrados por Pedro y Pablo en el libro de los Hechos de los Apóstoles. Uno de estos casos nos relata la entrada de Santiago con sus discípulos a una ciudad grande cercada por murallas, llamada Roma la Pequeña, donde se adoraba a los ídolos; junto a la puerta se toparon con un pobre llagado que pidió al Apóstol, y éste le respondió que no tenía dinero, pero si quería le podía dar "la plenitud del Señor". El pobre al momento lo acusó de "mágico grande" lo que le conduce ante un tribunal que lo interroga sobre sus poderes, estableciéndose una larga disputa en términos semejantes a los referidos en los textos del Nuevo Testamento.

En distintos momentos de los viajes se intercalan - sin orden cronológico - la subida al monte como alusión de la vuelta al Monte Santo de origen, al lugar donde se enterró el libro y en cuya cueva se 
escribió la Historia de la Verdad del Evangelio. Y es en este mismo lugar donde se hace referencia varias veces a la misa que celebró Santiago para sus discípulos. Allí mismo se le mostraría también al Apóstol lo referente al Libro de los Misterios Grandes.

En su conjunto, los trabajos misioneros de Santiago se caracterizan por el fracaso y por el rechazo de sus enseñanzas, que chocaron con las prácticas paganas de los habitantes de la Hispania antigua, colonizada por un importante número de familias romanas gentiles. Se insiste frecuentemente en la oración de Santiago a Dios en la que le pide paciencia para soportar la dura prueba. En uno de los momentos de enfrentamiento con los gentiles, en los que Santiago oraba y pedía fuerzas, vino el Espíritu y le alentó a tener paciencia, porque Dios dirige al que quiere, tiene providencia y sabe todas las cosas, recomendándole que ofreciera sacrificios y fuera justo en los mandamientos.

Cuando las dificultades eran mayores y el desánimo anidaba en el corazón del Apóstol, recordaba la profecía de la Virgen cuando le encargó que viniera a España a enterrar la Verdad del Evangelio: "Cuando acabares el negocio predica en la tierra sobredicha y no salgas de ella hasta que crea un varón. Y esto para experimentar tu paciencia para la predicación" " . Cansado de la espera y estando un día en oración, le pidió a Dios que le revelara en qué lugar encontraría al siervo que iba a creer en sus palabras. Y entre duerme y vela le fue revelado de nuevo que tuviera paciencia, que no descuidara la meditación y que se toparía con un árabe de buen corazón, de nombre Aben Almogueira, que adoraba a los ídolos sin mucho convencimiento. Éste sería el que se convertiría con su predicación, engrosando así el número de sus discípulos. En efecto, fue bautizado "con agua clara" por Santiago, que lo incorporó al número de sus discípulos dándole el nombre de Indalecio.

Una vez cumplido el encargo de la Virgen, y tras cinco años de difícil trabajo, Santiago y sus discípulos retornan a Tierra Santa para dar cuenta a María de la misión cumplida y de los esfuerzos evangelizadores, de los que Indalecio era elocuente testimonio y fruto. Se dirigieron a casa de la Señora, que, cuando los ve entrar con el nuevo converso, les da la bienvenida. Santiago le relata los avatares de la misión cumplida y le muestra a Indalecio. Se entabla un nuevo diálo-

7 Ibid. 
go con la Virgen en el que la Señora le anuncia proféticamente su muerte y su asunción al cielo. Termina este libro con la licencia para la predicación que da al grupo de los discípulos el Vicario, san Pedro, que además encarga a Santiago que escriba varios libros, entre ellos el del Fundamento de la Fe.

La muerte del Apóstol se relata en el libro de la Parte segunda del libro de las acciones de Jacobo Apóstol, breve composición que repite una vez más las peripecias y rechazos acaecidos durante su misión evangelizadora. Al final de su vida, Santiago recomienda a sus discípulos que antes de morir lo trasladen a las tierras de España, que guarden los libros junto al de la Verdad del Evangelio que él mismo había enterrado, y les prohíbe que le den sepultura en el Monte Santo, ordenándoles que lo hagan cerca del mar Océano. Los discípulos, siguiendo sus órdenes y viendo cercana su muerte, cumplieron su encargo. Atravesando el mar Mediterráneo por el Estrecho trasladaron al Apóstol al mar Océano, y muerto éste lo enterraron en un monte alto sobre el mar - Compostela-, viajando después por tierra para guardar los libros en el monte donde estaba enterrado la Verdad del Evangelio.

\section{La vida de san Cecilio}

Varias son las noticias que ofrecen los textos de los hallazgos sobre san Cecilio. Si se ordenan los datos dispersos contenidos en el pergamino de la Torre Turpiana, en la lámina martirial hallada junto a los restos, y en los llamados libros plúmbeos, se puede elaborar una breve historia acerca del primer obispo de Granada. Esta supuesta biografia es la que se fue divulgando en la religiosidad popular después de conocidas las traducciones de los textos, y con el tiempo dio lugar a las biografías que se insertaron en las historias de Granada y en otras publicaciones a las que me referiré más adelante.

Los primeros pasos de la vida de san Cecilio, los datos sobre su familia y su elección, nos los ofrece uno de los libros plúmbeos, en concreto el titulado Libro de los hechos de nuestro Señor Jesús y de la Virgen María su madre, y de su vida y milagros desde el día de su advenimiento hasta su muerte y ascensión al cielo, de Tesifón Aben Athar, discípulo de Jacobo Apóstol. El autor de este libro es otro de los varones apostólicos, que se presenta como hermano de Cecilio, 
cuyo nombre originario era Aben Alradi. Su padre se llamaba Caleh Aben Athar, de origen y nación árabe, de la provincia de Hus de Asia Menor. Una experiencia inolvidable marca la vida de ambos hermanos: conocieron personalmente a Jesucristo, que los curó de una enfermedad congénita y los encomendó al cuidado del apóstol Santiago. El encuentro con Jesucristo será decisivo, como las vocaciones que narran los Evangelios, en las que el Señor incluso le impone un nuevo nombre a aquél a quien llama. Según la narración, Tesifón era ciego de nacimiento y Cecilio sordomudo. Su padre se compadecía de ellos, y al oír hablar de Jesucristo y de los milagros que obraba, montó en camellos a sus hijos encaminándose hacia Galilea. Al encontrar a Jesús, Caleh, el padre de ambos hermanos, le dijo:

“Oh Señor mío, yo vengo a vos encaminado sobre tierra de Dus para que curéis estos dos hijos de ceguera y mudez y sordera. Yo os he visto que sois grandemente bienhechor y confío en vos, y estoy cierto que no los curará en el mundo otro sino vos, sin duda."

Y díjole Jesús a Caleh:

"Grande es tu fe y ya haré cumplidamente lo que pretendes." Y entonces tomó tierra en la palma de su mano y echó en ella su saliva y púsola sobre mis ojos y vi. Y mandóme que lo lavase en el lavabo del templo. Y puso la mano sobre la cabeza de mi hermano Aben Alradi y sopló en su boca tres veces, y sanólo y llenólo de sabiduría. Y habló en diversidad de lenguas, y lo primero que dijo fue: 'Testifico que no hay otro Dios que Dios y tú su Espíritu Verdadero'."

Y díjole Jesús, Nuestro Señor:

"Tú eres Cecilio".

Y fue con prosperidad este nombre que le puso Jesús, Nuestro Señor, significando con él "predicador de la fe, conquistador de ella".

Entonces volvió a mirar a su discípulo Jacobo Apóstol, superior nuestro, y díjole:

"Estos dos serán discípulos santos para la victoria de la ley. Recíbelos en tu amparo como conviene para ello" 8 .

Sorprende el parecido de la llamada o vocación de Cecilio con la de Pedro en el Nuevo Testamento, y que ésta se haga en el libro dedicado a los actos de Jesús equivalente al citado texto bíblico. La estrecha conexión con el apóstol Santiago es uno de los temas que más se destacan en las narraciones de los textos. En la lámina sepulcral se presenta a Cecilio como discípulo de Santiago. También, en varios

${ }^{8}$ Libro de los actos de Nuestro Señor Jesús y de sus milagros y de su Madre, María la Virgen, en Hagerty, M. J., Los libros, 92-93. 
pasajes de los libros plúmbeos se nombra a los discípulos del Hijo del Trueno, entre los que siempre aparece Cecilio. Así, cuando Santiago sale de Tierra Santa para predicar el evangelio en España, narra el apóstol cómo juntó a sus “discípulos Tesifón Árabe, y a su hermano Cecilio, e Hiscio Hebreo, y Torcuato Ario de Phetón, y Eufrasio Caldeo, y Segundo Samaritano" 9.

Pero donde de forma más patente se manifiesta esta relación entre maestro y discípulo es en el encabezamiento de aquellos libros plúmbeos que tienen a Cecilio por autor. Se dice que fueron redactados por éste, como notario de su maestro Santiago y siguiendo su mandato. De los libros que conocemos, se atribuye a Cecilio la autoría de once: los dos libros de Lo comprensible del Divino Poder; el Catecismo menor; la Historia del sello de Salomón; la Relación de la casa de la paz y de la venganza y de los tormentos; La naturaleza del ángel y de su poder; las Sentencias sobre la fe; el Libro de los enigmas y misterios que vio la Virgen en su coloquio con Dios; Los grandes misterios que vio Santiago apóstol en el Monte Santo, y los dos libros o las dos partes de los Hechos del apóstol Santiago.

El que apareciera Cecilio como escritor de estos libros fue uno de los datos más significativos para la iglesia granadina, ya que tal hecho confería a su obispo fundador una especial autoridad, por ser redactor de unos libros dictados a él por uno de los más singulares apóstoles de Jesucristo, el que desde las tradiciones medievales se tenía como evangelizador y patrón de España. Incluso alguno de estos libros los mandó escribir la Virgen en lengua árabe, encargo que realizó personalmente Cecilio: "Libro de las sentencias acerca de la ley y dirección. Consíguese con ella la seguridad y el lugar del descanso. Enseñado por Santa María Virgen pura, a Jacobo, hijo de Xameh el Zebedeo, Apóstol. Traducido por mandato de ella en arábigo por mano de Cecilio Aben Alradi, discípulo y notario del Apóstol" 10.

De esta forma se presenta como un autor de textos con similar autoridad a los neotestamentarios. La causa de que este aspecto no se destaque en las vidas de san Cecilio que han pasado a la tradición popular se debe a que desde el primer momento los libros plúmbeos y su contenido estuvieron bajo sospecha, y sobre todo, al hecho de que más tarde fueran condenados oficialmente por la Santa Sede. Lo cual

9 Libro de la Historia de la Verdad del Evangelio, en id., p. 129.

10 Libro de las sentencias acerca de la Ley, en id., p. 185. 
resulta lógico, ya que la autoría de Cecilio tenía realmente como finalidad conferirle una autoridad especial en la tradición eclesial, verdadera intención, según mi opinión, de los inventores de estos sorprendentes textos.

Otro documento que aporta importantes datos biográficos sobre Cecilio es el pergamino encontrado en los cimientos de la Torre Turpiana. Según los textos árabes que ocupaban la parte central del documento, Cecilio, en su viaje de Tierra Santa a España, paró en Atenas donde conoció al obispo de aquella iglesia, san Dionisio Areopagita, que lo recibió en su casa. Allí le mostró uno de sus más preciados tesoros, una profecía desconocida del evangelista y apóstol Juan escrita en árabe, en la que se daban importantes noticias para el futuro de la cristiandad. Cecilio la consiguió, traduciéndola al castellano. Además, recibió del obispo Dionisio la preciada reliquia de un paño que utilizó la Virgen para secarse las lágrimas en la pasión de su Hijo Jesucristo. Por otra parte, el texto latino del escrito en cuestión daba por primera vez a la sede de Cecilio el nombre de Granada, y proféticamente anunciaba la presencia de los musulmanes en la ciudad, al pedir el obispo a su presbítero Patricio que escondiera el contenido de la caja para que no cayera en poder de los moros.

Por su parte, la lámina sepulcral proporciona las noticias sobre los últimos días de la vida de san Cecilio. De nuevo se habla de él como "discípulo de Santiago, varón dotado de letras, lenguas y santidad". Se confirma así el conocimiento de lenguas como el árabe y el castellano. Y se dice que padeció martirio en el año segundo del imperio de Nerón - es decir, hacia el año 56-, el día primero de febrero, en el mismo sitio donde tuvieron lugar los hallazgos, junto a dos discípulos más, los santos Septentrio y Patricio. Este último fue el encargado de esconder las reliquias y el pergamino en los cimientos de la Torre Turpiana.

\section{La Virgen según las invenciones}

Entre los primeros hallazgos de 1588 - es decir, entre los objetos que contenía la caja encontrada bajo la Torre Vieja o Turpiana-, destacó sobremanera el paño que, según relataba el pergamino encontrado junto a él, perteneció a la Virgen y fue usado por ella a modo de lienzo para secarse los ojos en la Pasión de su Hijo. De éste se hicie- 
ron dos partes. Una se envió a Madrid por mandato expreso de Felipe II, que lo guardó en los relicarios del Monasterio de El Escorial. La otra se depositó en la Catedral de Granada, donde recibió culto solemne durante los siglos posteriores. Nada sabemos de la tablita pintada con una imagen de Nuestra Señora, pero sin duda es un dato más que documenta la importancia de la devoción a la Virgen de la que los hallazgos eran testimonio vivo.

No menos importante es la mención y el lugar que dedican a la Virgen los libros plúmbeos. Excepto en dos de ellos, el Libro de la Esencia de Dios y El llanto de San Pedro - curiosamente los más breves-, todos los demás que tienen texto legible hacen referencia en mayor o menor grado a la Virgen María. Concretamente, seis de estos tienen a María de distinta forma como principal personaje en su trama argumental: el Libro de los galardones de los creyentes basado en ocho preguntas hechas a la Virgen; el Libro del coloquio de María sobre las misteriosas revelaciones que vio la Santa Virgen en la noche de su coloquio espiritual con Dios; el Libro de las sentencias y el $L i$ bro de la historia del sello de Salomón revelados ambos por Santa María Virgen a Santiago; y el Libro del don del Lugar basado en las enseñanzas de Santa María, al igual que el Libro de la naturaleza del Ángel.

Sin duda ninguna, puede afirmarse que el personaje principal de los libros plúmbeos es la Virgen María, que aparece en ellos como la depositaria del mensaje de Dios, la que lo revela y enseña, la gran maestra de la Nueva Iglesia. Ella fue constituida por el mismo Dios, juntamente con los Apóstoles como "testigos de la Verdad" "11. Pero no es un testigo cualquiera, sino la encargada de revelar esa Verdad a los mismos apóstoles por mandato divino según nos dirá el propio Santiago: “Juntó la comunidad nuestra de los doce apóstoles Santa María Virgen en su casa después de la venida del Espíritu Santo, y de haber brotado las lenguas en nosotros y dijo: 'Hame sido mandado por revelación de Dios por el ángel Gabriel que os diga esto, y que os muestre la Verdad del Evangelio glorioso que hizo que bajase a mí después que le hablé espiritualmente"" ${ }^{12}$. Algunos otros pasajes nos muestran a la Virgen como la encargada de revelar a los discípulos la Verdad del Evangelio,

${ }^{11}$ Cfr. Libro de los dones del Galardón que se ha de dar a los que creyeren la Verdad del Evangelio. Hay en el ocho preguntas a Santa Maria, id., p. 144.

${ }_{12}$ Libro de la historia de la Verdad del Evangelio, id., p. 119. 
destacando por su significación la petición expresada por Pedro, en calidad de príncipe y cabeza del colegio apostólico: "Dinos la Verdad del Evangelio y de los galardones de ella, oh Señora Nuestra" ${ }^{13}$. Y no olvidemos que, según los mismos libros, el contenido de "la Verdad del Evangelio es el alma del Evangelio y tesoro de los tesoros del trono" ${ }^{14}$. $\mathrm{O}$, lo que es lo mismo, la quintaesencia del Evangelio. De esta forma se da un mutuo intercambio: la autoridad de los libros confirma la trascendencia de la Virgen, y a su vez el lugar insustituible de ésta en la tradición cristiana autentifica el valor de aquéllos.

Ciertamente, y en consonancia con la tradición y devoción popular, los Apócrifos del Sacromonte presentan a María como el alma de la Iglesia naciente, la que presidía en la fe al colegio apostólico. Su casa era el lugar habitual de reunión ${ }^{15}$, donde ejercía su magisterio enseñando a los discípulos escogidos de su Hijo ${ }^{16}$. En especial ejerce esta labor con Santiago ${ }^{17}$, que en todo momento aparece como el apóstol elegido que recibe unas especiales revelaciones y el encargo particular de venir a misionar a España ${ }^{18}$. Pero los libros no sólo se centran en la obra de María, en su misión en relación a la Iglesia. Estos textos contienen lo que podríamos llamar toda una mariología o, lo que es lo mismo, un tratado sobre la Virgen, su persona y su obra, la esencia misma de su ser. Ante todo María se presenta como la mujer que, conservando perpetua virginidad ${ }^{19}$, es Madre de Jesús. Así, cuando se nombra a Jesús a continuación se dice casi siempre "el hijo de María" ${ }^{20}$. La maternidad de María tuvo lugar por el misterio de "la encarnación de Nuestro

13 Libro de los dones de Galardón, id., p. 133.

14 Ibídem.

15 Otras referencia además de la ya citada en que la Virgen reúne en su casa a los apóstoles las encontramos en el Libro de los dones de Galardón, id., p. 131; Libro del coloquio de Santa María Virgen, id., p. 147; Libro de las acciones de Jacobo apóstol y de sus milagros, id., p. 206, etc.

${ }^{16}$ Libro de la relación del don del lugar de la paz y del tormento, id., p. 292; Libro de la naturaleza del Ángel y su poder, id., p. 302.

${ }_{17}$ Cfr. Libro de los actos del Señor Jesús y de sus milagros y de su Madre María la Virgen, id., p. 99.; Libro de las acciones de Jacobo Apóstol y de sus milagros, id., p. 207 y 240 .

18 Cfr. Libros de las acciones de Jacobo Apóstol y de sus milagros, id., p. 208.

19 Cfr. Oración y defensorio de Santiago, en id., p.89; Libro del conocimiento del divino poder y tolerancia y aceleración en las criaturas, id., p. 266; Parte segunda del conocimiento del Divino poder, id., p. 273.

${ }^{20}$ Cfr. Libro de la relación de la Misa de Jacobo, id., p. 73; Oración de defensorio de Jacobo,... que le enseñó Jesús, Hijo de María, su Maestro, id., p. 98 y 90; Libros de las acciones de Jacobo y sus milagros, id., p. 210, 237 y 249-50; etc. 
Señor Jesús, que fue por obra del Espíritu Santo en María, antes del parto y en él y después de él" ${ }^{21}$, misterio que se narra en términos muy parecidos a los del evangelio de Lucas:

"Y cuando llegó el tiempo determinado de haberle de concebir, Santa María, según ella dijo, cuando bajó a ella el fiel Gabriel y le anunció que le había de concebir ella rezaba en el libro y díjole: 'Oh Santa María, oh llena de gracia, Dios es contigo, bendita tú entre las mujeres'...

Y cuando oyó lo que le decía turbose y levantó la cabeza acogiendo a Dios, pensando quien sería el que hablaba. Y formósele Gabriel en honesta forma humana que resplandecía con luz refulgente. Y dijole: 'No temas, porque Dios te ha dado su gracia. Ciertamente te ha dado en tu vientre por hijo el verbo del Altísimo. Y llamarle has Jesús, de la casa de David. Y habitará en la casa de Jacob para siempre. Y su reino no se acabará jamás'.

Y díjole: ‘¿Cómo será esto porque no he conocido varón ni lo apetezco’.

Respondiole el ángel: 'Esto es fácil para Dios, sobreviniendo su Espíritu Santo sobre ti. Y cuando haya nacido se llamará Verbo de Dios Altísimo'.

Y dijóle: 'Dame señal para esto'.

Y díjole: 'Isabel, tu parienta, está empreñada de seis meses en su mayor edad de más de su esterilidad, y todo es fácil a Dios'. Y entonces dijo María: 'Yo soy sierva del Señor. Sea así cierto como lo dices"” ${ }^{22}$.

En este mismo Libro de los actos de Nuestro Señor Jesús y de sus milagros y de su Madre, María la Virgen, se narran otras tantas historias de la vida de María, como el alumbramiento de su Hijo, la marcha de la Sagrada Familia a Egipto, sus costumbres, etc. En líneas generales son patentes las influencias de los evangelios apócrifos y de las demás tradiciones de carácter devocional, con detalles de tipo anecdótico y de clara influencia popular como por ejemplo el situar el "nacimiento en el rigor del frío; y nevada aquella noche" ${ }^{23}$.

\section{Inmaculada: "A María no tocó el pecado primero"}

De entre todas las referencias a la vida y a la persona de María destaca una, tanto por su cantidad numérica, como por su importancia en el contexto histórico y por sus influencias en la sociedad de su tiempo. Una afirmación que, desde sus orígenes, se identificó íntima-

${ }^{21}$ Libros del excelente bienaventurado apóstol Jacobo id., p. 79.

22 Libro de los actos de Nuestro Señor Jesús y de sus milagros y de su Madre, María la Virgen, id., p. 97-98. La cita correspondiente del Evangelio es Lc 1,26-38.

${ }^{23}$ Id., p. 101. 
mente con el núcleo del contenido doctrinal de los libros plúmbeos. Me refiero en concreto a la tesis que defendía que María no tuvo el pecado original o, lo que es lo mismo, que fue concebida pura y sin mancha, Inmaculada en el lenguaje de la Iglesia católica.

Al hablar de la referencia que hacen los libros a la Inmaculada, habitualmente se ha citado como único texto el que se hizo popular y al que hemos aludido en el epígrafe anterior. Pero al estudiar el contenido de los libros, hemos encontrado con sorpresa que son diez las ocasiones en que se hace explícita mención a la concepción Inmaculada de María. No siempre con la misma frase, aunque sólo se utilicen dos expresiones, gráficas y significativas. La más frecuente es la palabra pureza empleada en el sentido de limpieza o ausencia de pecado, así: "María Virgen pura" ${ }^{24}$. Una variante que especifica el sentido de la pureza en relación con la concepción Inmaculada es la de "María Virgen, pura de pecado en todas maneras" ${ }^{25}$, o "María escogida con virginidad y pureza de pecado" ${ }^{26}$. Con todo, otra expresión de temática inmaculista es la que ha quedado asociada como frase más emblemática de estos libros, hasta tal punto que pasó a ser el lema del escudo-insignia de la Abadía del Sacromonte y que el mismo arzobispo Castro la incorporara como anagrama a su pontificado. No es otra que "a María no tocó el pecado primero" ${ }^{27}$. También aparece este concepto en su aspecto positivo: "Y si la comprehendiera el pecado original se apartaran de ella sus hermosuras, y la tocara la aprobación en la concepción y en el parto tocándola" ${ }^{28}$.

Otro pasaje expresa el concepto de limpieza de pecado como el no haber sido tocada por el mismo: "Y aquella bendición es por ser ella limpia del pecado original... Porque fuera de ella, después de Adán, a todos comprendió la mancha por el pecado. Y a ella no la comprehendió por la limpieza de ét' ${ }^{29}$. En esta misma línea está el texto que asimila el pecado a la soberbia: "Es la Virgen María, limpia de

\footnotetext{
${ }^{24}$ Libro de los Actos de Nuestro Señor Jesús y de sus milagros y de su Madre María la Virgen, op. cit., p. 95; Parte segunda del Libro de las acciones de Jacobo Apóstol, id., p. 243; Libro de las Sentencias acerca de la Ley, id., p. 185.

${ }^{25}$ Libro del coloquio de Santa María Virgen, id., p. 151 y 162.

${ }^{26}$ Parte segunda de la noticia del Divino Poder, id., p. 273.

27 Libro de los Fundamentos de la Ley, id., p. 65.

${ }^{28}$ Libro del conocimiento del Divino poder y tolerancia y aceleración en las criaturas, id., p. 267.

${ }^{29}$ Libro de los actos de Nuestro Señor Jesús y de sus milagros y de su Madre, María la Virgen, id., p. 97.
} 
pecado en todas maneras. Y la soberbia no la tocó nada de ella jamás" 30 .

\section{Los personajes sacromontanos en la historia de la Iglesia}

En grandes pinceladas éstos son los datos que nos ofrecen los textos plúmbeos sobre Santiago, san Cecilio y la Virgen, los que sin duda aparecen, junto con Jesucristo, como los personajes principales de la trama argumental de los hallazgos. Su elección para este papel no es circunstancial, respondiendo sin duda a un plan preconcebido que pretendía dar respuesta a parte de la compleja problemática que se vivía en aquel momento histórico, desde el punto de vista social, político, económico y religioso. Pero sin duda en aquel contexto la dimensión religiosa desempeñaba un lugar destacado, en parte como aglutinante de las demás.

Para empezar, con la elección de estos personajes, queda meridianamente claro que quienes urdieron tan complicada trama eran perfectos conocedores tanto del pensamiento de la teología católica y de la historia del Iglesia en España, como de aquellos aspectos pasados que más y mejor afectaban al presente histórico. De una manera tan notable que me atrevería a situar entre sus creadores, más que a meros eclesiásticos, a teólogos de la Iglesia. En este sentido creo que se ha insistido en la influencia y preeminencia de la cultura e historia islámica en los textos plúmbeos, relegada a un segundo término la católica, descartando su posible predominio y protagonismo sobre la anterior y opositora. Porque en el caso de los personajes que nos ocupan y de la visión que de ellos se nos da, hemos de hablar en grandes líneas de sintonía con el pensamiento católico, con el que nunca se entra en conflicto. Muy al contrario, uno de los objetivos parece ser completar aspectos desconocidos, sin que las noticias nuevas que aportan puedan considerarse contrarias a la visión eclesial de los mismos. Y, lo que en aquella cultura era más importante, su plena consonancia con los datos - históricos o procedentes de la tradición medieval - admitidos entonces en gran parte como ciertos por la religiosidad popular.

${ }^{30}$ Libro del coloquio de Santa María Virgen, id., p. 155. 
Mi propuesta consiste fundamentalmente en hacer una lectura de los contenidos doctrinales y de todo lo acaecido que tenga en cuenta no sólo y principalmente la problemática islámica y su historia, sino que se inicien en los orígenes del cristianismo peninsular, en la visión histórica y la problemática doctrinal que de estos hechos se tenía en la Edad Moderna. Y, partiendo de aquí, constatar la influencia de las invenciones en la literatura y la religiosidad católica posterior, a pesar de la condena expresa de Roma.

Para comprender mejor los hechos, hemos de recordar las inquietudes que laten tras ellos. Muy especialmente el ansia por conocer cómo y dónde tuvo origen la evangelización peninsular. $\mathrm{Y}$ esto no sólo para los granadinos recientemente incorporados a la cultura castellana y cristiana, sino para el resto del territorio nacional. No olvidemos que el llamado "apogeo de la problemática santiaguista" ${ }^{31}$, se ubica entre 1574 y 1630 . Coincidiendo en el tiempo, por tanto, con el hallazgo de las supuestas reliquias martiriales y de los libros plúmbeos, que tiene como argumento principal los orígenes del cristianismo en la Hispania romana por la predicación de Santiago y sus discípulos. Sin olvidar que es en esta época cuando surge con especial fuerza la problemática en torno a la venida del apóstol Santiago y su patronazgo sobre España, el Voto de Santiago, etc. Es el tiempo en que Ambrosio de Morales publica la Crónica General de España y recorre la península por orden de Felipe II recogiendo reliquias, especialmente de los primeros cristianos.

Pero, como ya he indicado, estos problemas no se circunscriben sólo al ámbito local, llegando incluso a sobrepasar el marco territorial de la Monarquía Católica. Buena prueba de ello es que el enfrentamiento entre el Primado de Toledo y el Arzobispo de Compostela - motivado por negar el primero la predicación del apóstol Santiago en España y defenderla a ultranza el segundo-, llegó hasta la Sede Romana dando lugar a que el afamado consejero del Pontífice y padre de la Historia de la Iglesia, el Cardenal César Baronio, llegara a afirmar que la venida de Santiago a España era solamente una antigua tradición y que, como tal, no debía conmemorarse como solemnidad en el Breviario Romano por las iglesias hispanas. El asunto llegó a adquirir dimensiones de incidente diplomático entre la Corona espa-

${ }^{31}$ Rey Castelao, O., Historiografia del Voto de Santiago. Recopilación crítica de una polémica histórica, Universidad de Santiago de Compostela, 1985, 38-130. 
ñola, defensora a ultranza de la evangelización y patronazgo de Santiago, y la Santa Sede.

Desde esta perspectiva resulta empobrecedor el enfoque unilateral con que se ha venido tratando el tema, limitando casi exclusivamente el origen de las invenciones a la guerra de las Alpujarras, a la primera expulsión y al problema morisco. Visión del todo incompleta ya que, y es mi opinión, un estudio en profundidad sobre los Apócrifos del Sacromonte 32 no puede perder de vista sus fundamentos en la historiografía cristiana medieval.

\section{Algunas consideraciones sobre Santiago en la tradición hispana}

La imagen de Santiago que nos presentan los textos plúmbeos tiene como base las tradiciones cristianas medievales, profundamente arraigadas en la religiosidad hispana. Pienso que las dos grandes tradiciones medievales que justifican los orígenes del catolicismo español son también parte de los fundamentos últimos de las invenciones granadinas de finales del Quinientos, dato que no puede olvidarse en su interpretación. En concreto me refiero a los relatos sobre la predicación de Santiago en España y a los siete Varones apostólicos. La primera tiene su origen en el Breviarium apostolorum ${ }^{33}$, datado hacia el 600, si bien el desarrollo de la misma aparece en un documento de finales del siglo XIII o comienzos del XIV existente en archivo de la Basílica del Pilar. Relata cómo Santiago recibió de Cristo el encargo de venir a España a predicar el Evangelio, y antes de partir "se dirigió a la Virgen, le besó las manos y le pidió con piadosas lágrimas la licencia y bendición. La Virgen le dijo 've, hijo; cumple el precepto de tu maestro"" ${ }^{34}$. Saliendo de Jerusalén llegó a España donde predicó por varias ciudades; en una de ellas convirtió a un pagano a la fe. Predicaba de día, y de noche se iba junto a un río donde, después de un breve reposo, se entregaba a la oración apartado del ruido de los hombres y de las molestias de los gentiles, etc. La lectura del documento 1979.

${ }^{32}$ Cfr. Alonso, C., Los Apócrifos del Sacromonte. Estudio histórico, Valladolid

33 Gaiffier, B. de, "Le Breviarium apostolorum", Analecta Bollandiana, LXXXI (1963), 89-116.

${ }^{34}$ El texto sobre la predicación de Santiago en Espana lo tomamos de la traducción que de él hace García Villada, Z., S.I., Historia Eclesiástica de España, tomo I, 1. parte, Madrid, 1929, 73-76. 
nos recuerda en mucho la vida de Santiago que nos ofrece el libro plúmbeo dedicado al Apóstol.

Sin embargo, opino que la mayor influencia que manifiestan los inventores proviene del segundo documento que he indicado, las llamadas actas o vidas de Los siete Varones apostólicos. Esta leyenda, al menos tal como ha llegado a nosotros, relata cómo los santos apóstoles - se sobrentiende san Pedro y san Pablo-, ordenaron obispos en Roma a siete varones y los enviaron a evangelizar a España. Los nombres de éstos eran Torcuato, Tesifón, Indalecio, Segundo, Eufrasio, Cecilio y Hesiquio. Al llegar a Guadix —en la actual provincia de Granada-, donde celebraban las fiestas en honor de los dioses de la Tríada Capitolina, fueron reconocidos como cristianos y perseguidos por sus habitantes hasta el río. Los siete obispos consiguieron en su huida atravesar el río, pero muchos de los accitanos perseguidores, con peor suerte que ellos, perecieron al hundirse el puente por el peso de la muchedumbre. Este acontecimiento fue considerado como un hecho milagroso entre el pueblo pagano, por lo que una noble señora llamada Luparia, después de hablar con los varones, se convirtió junto a muchos de los habitantes que al principio los rechazaron. Antes de recibir el bautismo, y siguiendo los consejos de los santos predicadores, la piadosa matrona construyó un baptisterio y una basílica, dedicando el altar a san Juan Bautista. Después de estos prodigiosos hechos, los siete obispos se dispersaron por otras tantas ciudades, permaneciendo Torcuato en Guadix, mientras Cecilio llegó a la cercana Iliberri, la antigua Granada, donde según esta misma tradición fundó su Iglesia.

Esta narración nos ha llegado a través de manuscritos del siglo $\mathrm{X}$, si bien parece basada en documentos litúrgicos más antiguos, como oracionales, martirologios y calendarios mozárabes que pueden datarse hacia el siglo VII. Con anterioridad no se hace mención de ellos en ningún otro documento, ni juntos ni por separado. Aparecen por primera vez en el martirologio del siglo IX, mientras no los nombran los anteriores. Tampoco aparecen en ninguna de las largas listas de santos que recogen las inscripciones visigóticas de la Bética, para conmemorar la dedicación de basílicas o las reliquias depositadas en los altares de las mismas.

Desde hace tiempo los historiadores de la Iglesia vienen demostrando que este relato carece de valor histórico, tratándose de una de tantas narraciones legendarias que ven la luz en la alta Edad Media, época 
pródiga en narraciones similares ${ }^{35}$. Se considera invención de un hagiógrafo mozárabe poco escrupuloso huido de la Bética hacia el norte peninsular, donde concibió esta fantástica leyenda allí donde nadie podía contradecirle, tomando al parecer los nombres de unas listas de obispos que ya circulaban desde más antiguo. También los martirologios tardíos que conmemoran su fiesta son de alguna manera una prueba más de la ausencia de un culto antiguo a estos santos varones. El martirologio romano conmemora la fiesta de los siete varones el 15 de mayo, lo que significaría, al no considerarlos mártires la leyenda, que todos murieron el mismo día pero en distintas diócesis, circunstancia ésta que dificulta aún más la credibilidad de la leyenda. De lo que se deduce que es ésta el origen del culto y no al revés.

Dejando a un lado la problemática en torno a su historicidad, a nosotros nos interesa la manifiesta influencia - casi copia literal me atrevería a decir - de esta tradición en los textos plúmbeos, a la que incorpora la anterior tradición jacobea de las andanzas evangelizadoras del Patrón de las Españas. Aquí radica, pienso yo, uno de los puntos de interés de nuestras invenciones, que sintetizan las tradiciones medievales con los mismos fines con que éstas nacieron pero aplicándolos al ámbito localista granadino, con el objetivo claro de fundamentar el origen e idiosincrasia cristiana del territorio del Reino de Granada frente al dominio de un pueblo de cultura y religión diferentes. El pueblo y la cultura es el mismo, el Islam. Lo que sucede es que en los hallazgos sacromontanos no se rechaza la cultura musulmana, sino que se integra con las tradiciones medievales por la lengua, el origen de los personajes, las alabanzas que a ellos dedica la Virgen y sobre todo por aparecer junto al credo cristiano elementos del credo islámico.

Puede afirmarse que, sin duda, el concepto sobre los orígenes del cristianismo en España que exponen los libros plúmbeos tiene como fuentes documentales las dos tradiciones medievales, la predicación de Santiago y la leyenda de los Varones apostólicos. Los nombres de éstos, que aparecen en los apócrifos granadinos como discípulos de Santiago unidos en su empresa de evangelizar la Hispania romana, son los mismos: Cecilio y su hermano Thesiphón, Torcuato, Segundo, Hiscio y Eufrasio. Aparecen dos originales novedades: la ausencia de Indalecio, que se incorporaría al resto del colegio en otro momento de esta narra-

${ }^{35}$ Cfr. Vives, J., "Tradiciones y leyendas en la hagiografia hispánica”, Hispania Sacra, 17 (1964), 506. 
ción siendo el converso que la Virgen anunció al Apóstol, y la condición de narrador de la historia de uno de ellos, Cecilio, el mismo que aparece en el pergamino de la Torre Turpiana y en las láminas martiriales. Esto suponía un dato clarificador a la vez que un importante avance sobre el origen del cristianismo peninsular, al confirmar la unidad de dos de las más estimadas tradiciones medievales, tenidas ambas por ciertas en la época de los hallazgos tanto en sectores cualificados de la sociedad como entre el pueblo fiel. De nuevo aparece el eco de las dos tradiciones con los sucesos acaecidos en la llegada a Acci, la actual ciudad de Guadix; con la cercanía del río, que aquí lógicamente es el Darro; con apartarse para orar; con que a Santiago también aquí se le aparezca la Virgen, como en Zaragoza, etc.

Pero sobre todo, con la aparición de los restos de san Hiscio, san Tesifón y san Cecilio y de sus correspondientes láminas martiriales - en las que se los reconocía como discípulos de Santiago-, se cerraba un ciclo histórico en toda la cristiana España. Ya se habían encontrado y recibían culto cuatro de los varones apostólicos. Las reliquias de san Eufrasio, primer obispo de Andújar, recibían culto en el templo de Valdemar desde el 716; las de san Torcuato de Guadix, primero en Santa Coloma hacia el 777, y más tarde en Celanova desde 977; las de san Indalecio, obispo de Pechina (Almería), en el monasterio de san Juan de la Peña desde 1084; y, finalmente, Ávila descubrió el cuerpo de san Segundo, su primer obispo, en 1519. Faltaban las reliquias de los otros tres varones apostólicos de las tradiciones medievales, que eran las halladas en Granada. En los libros plúmbeos se respeta la tradición de la sepultura del Apóstol en Compostela.

\section{Una nueva vida, la de san Cecilio}

Junto a Santiago aparece en la leyenda de los Varones apostólicos san Cecilio, otro de los personajes claves de las invenciones sacromontanas. Como ya he indicado, entre los datos biográficos que estos textos nos ofrecen sobre él, vuelven a aparecer los nombres de los varones, curiosamente identificando esta vez la procedencia de cada uno de ellos.

De nuevo hay que hacer mención aquí a otra de las tradiciones medievales sobre los orígenes de cristianismo en Granada. Desconozco si era conocida o no por los inventores de los apócrifos granadinos. 
Pero sí me consta que es una de las fuentes de la leyenda medieval de los Varones apostólicos ${ }^{36}$. Se trata de un documento, como en el caso anterior también del siglo $\mathrm{X}$ y basado en otros más antiguos, que se conserva en la Biblioteca de El Escorial, procedente del Monasterio de San Millán de la Cogolla, en un códice del 962 denominado Emilianense. El folio $360 \mathrm{v}^{\circ}$ contiene la lista de los obispos de las iglesias de Sevilla, Toledo y Granada desde su fundación. Se considera que estas dípticas episcopales "fueron copiadas por los académicos Sres. Diéguez y Rodríguez Campomanes en su segundo viaje literario a la Biblioteca de El Escorial y publicadas después en el tomo II de las Memorias de la Real Academia de la Historia, pág. 604. También nuestro P. Flores las publica en los tomos de la España Sagrada correspondiente a dichas iglesias. Las incluye D. Vicente de la Fuente en el episcopologio de la Iglesia visigoda en su Historia eclesiástica, $\mathrm{y}$ han sido utilizadas también en otras muchas partes" ${ }^{37}$.

El catálogo de la sede iliberritana contiene 62 nombres de obispos: Cecilio, Leubesindo, Ameanto, Ascanio, Juliano, Agústulo, Marturio, Gregorio, Pedro, Fabiano, Honasterio, Optato, Esteban,... En general, este documento merece confianza, ya que para su composición el redactor se sirvió de documentos más antiguos. Pese a ello, los obispos del período romano presentan omisiones y errores en las grafías y cambios en el orden sucesorio, mientras que los nombres de obispos correspondientes a la época visigótica, a partir de finales del siglo VI, son correctos en su mayoría, como se puede comprobar por las actas de los concilios visigóticos y otras inscripciones.

Valga como ejemplo el caso de Esteban, obispo de Iliberri que firmó las actas del III Concilio de Toledo (589) y del I de Sevilla (590). A su vez también aparece en uno de los documentos arqueológico-epigráficos más importantes de la Granada de esta época; me refiero a la inscripción existente en el Museo Arqueológico Provincial de Granada hallada en Valderrubio, que nos da cuenta de la muerte de Nocidio, "presbitero en el nombre de Cristo. Marchó en paz el día duodécimo de las kalendas de mayo (20 de abril) en el primer año de nuestro señor Esteban obispo".

\footnotetext{
${ }^{36}$ Cfr. Martínez Medina, F.J., Historia y tradiciones sobre los orígenes del cristianismo en Granada, Facultad de Teología de Granada, 1997, 13-19.

37 Antolín, G., "El Códice Emilianense de la Biblioteca de El Escorial", Ciudad de Dios, 74 (1907), 388.
} 
La lista de los de Granada se inicia con Cecilio, el mismo nombre que da la leyenda de los Varones apostólicos y los textos sacromontanos al primer obispo de Iliberri. En el segundo nombre, Leubesindo, encontramos uno de los trastrueques en el orden de sucesión, al tratarse con toda probabilidad de un nombre godo. El mismo error lo podemos comprobar al anteponer el nombre del obispo Gregorio, que como indicamos, está plenamente documentado en la segunda mitad del siglo IV, al de Fabiano o Flaviano, que figura en las actas del concilio de Iliberri, celebrado a comienzos del mismo siglo.

Éstos, aunque con el orden cambiado, son el primer fundamento histórico de la posible veracidad del catálogo. Pero si el lugar que ocupa Fabiano, de principios del siglo IV, es aproximadamente el suyo, los siete que le preceden, descontando a Leubesindo y a Gregorio, serían los correspondientes al siglo III. De aquí lógicamente se deduce que a Cecilio - el que encabeza la lista - es del todo imposible situarlo a mediados del siglo I para integrarlo en la leyenda de los siete Varones apostólicos y, por tanto, que sea el mismo Cecilio de la tradición medieval. Más probable sería pensar que el redactor tomó el nombre de Cecilio y de sus compañeros mártires de otras listas semejantes de las primeras iglesias hispanas aún no perdidas cuando él escribía su leyenda ${ }^{38}$.

Sabemos que a partir de la incorporación del Reino de Granada a la Corona de Castilla se admitía, siguiendo las tradiciones medievales, que san Cecilio fue el evangelizador de Iliberri, la antigua Granada ${ }^{39}$. Ésta fue la causa de que cuando se erigieron las primeras parroquias, en 1501, se le diera a una de ellas el nombre del Obispo fundador de esta Iglesia. A finales del siglo XVI surge una tradición según la cual la parroquial de san Cecilio se edificó sobre los cimientos de otro templo anterior que, consagrado con la misma advocación durante el período visigodo, permaneció abierto al culto durante toda la dominación musulmana ${ }^{40}$. En la historiografía del siglo XVIII se 73-178.

${ }^{38}$ Cfr. Vega, A.C., "De los obispos de Iliberri”, España Sagrada, 53-54 (1961),

${ }^{39}$ Cfr. Martínez Medina, F.J., "San Cecilio", en Diccionario de los Santos, dirigido por C. Leonardi, A. Riccardi, G. Zarri, vol. I, A-I, San Pablo, Madrid, 2000, 481-485.

${ }^{40} \mathrm{La}$ primera noticia aparece en la Crónica General de España, que continuaba Ambrosio de Morales, cronista del rey nuestro señor D. Felipe II, el monarca bajo cuyo reinado tiene lugar el hallazgo de los restos de san Cecilio y que desde el primer momen- 
llegó incluso a denominar este templo «la Catedral Mozárabe» ${ }^{41}$. Esta tradición no tiene ningún fundamento histórico, «y debido a las lagunas de la información sobre este extremo, hay que mostrar una gran reserva» ${ }^{42}$.

Similar actitud de reserva desde el punto de vista de la crítica histórica merece la noticia que refiere el empeño de los nuevos moradores cristianos de Granada por buscar los restos de su primer obispo desde los primeros momentos de la conquista. Relata cómo a finales de la segunda década del XVI, bajo la dirección del quinto presidente de la Real Chancillería, don Diego Pérez de Villamuriel, «se buscaron la primera vez en los contornos de Granada las Reliquias de su Patrón San Cecilio, que se decía estar sepultado dentro del Arzobispado». Su séptimo sucesor en el cargo, don Fernando Niño, hacia 1540, «continuó las diligencias de buscar el cuerpo de san Cecilio». Años más tarde, al no haber encontrado los granadinos los restos de su supuesto patrón y evangelizador, «los Prevendados de Granada, que acompañaron al Arzobispo Don Pedro Guerrero al Concilio de Trento, pidieron Reliquias Insignes para su Iglesia a Pío IV y les respondió: "Qué más reliquias deseáis, que las que tenéis en aquellos montes. Tomad un puño de tierra, exprimidla, y vertirá Sangre de Mártires» ${ }^{43}$.

Esta noticia aparece impresa por primera vez en el siglo XVIII, en un libro que se escribe como exaltación de D. Pedro de Castro y de su mayor obra, la fundación de la Abadía del Sacromonte, el santuario donde su guardaban y recibían culto los restos considerados como las reliquias de san Cecilio, el obispo que las tradiciones medievales da-

to se convirtió en defensor de los mismos. Pero quien defenderá esta tesis con más detalles, siendo la fuente principal de posteriores referencias, será el historiador F. Bermúdez de Pedraza, uno de los escritores que justificaría los hallazgos del Sacromonte en sus obras: Antigüedad y Excelencias de Granada, Madrid, 1608, p. 112; Historia Eclesiástica, Granada, 1638, 96, 110, 142

${ }^{41}$ Chica Benavides, A. de la, Gacetilla curiosa o demanario granadino, Papel XLIII, lunes 28 de enero de 1765.

${ }^{42}$ Arié, R., España Musulmana (Siglos VIII-XV), en Historia de España, t. III, dirigida por M. Tuñón de Lara, Barcelona, 1982, 192.

${ }^{43}$ Heredia Barnuevo, N., Mystico ramillete, histórico, cronológico, panegyrico, texido de las tres fragantes flores del nobilisimo antiguo origen, exemplarísima vida y meritísima fama pósthuma del Ambrosio de Granada, segundo Isidoro de Sevilla y segundo Ildefonso de España, espejo de juezes seculares y exemplar de eclesiásticos pastores, el Illmo. y V. Sr. Don Pedro de Castro Vaca y Quiñones, presidente integérrimo de las dos Chancillerías de España, dignísimo arzobispo de Granada y Sevilla y fundador magnifico de la Insigne Iglesia Colegial del Sacro Monte Ilipulitano, Granada, 1741, 2 y 3. 
ban como primer obispo y fundador de la Iglesia de Granada. La fuente documental del biógrafo del arzobispo Castro no fue otra que el proceso que se siguió a raíz de los hallazgos para la calificación de las supuestas reliquias de san Cecilio y de sus compañeros mártires. No resulta circunstancial este dato que confiere a la noticia antes referida una total parcialidad; ciertamente nadie antes que él hace referencia a la búsqueda de los restos de san Cecilio, a pesar de la importancia que hubiera tenido este hecho para la sociedad granadina de aquel tiempo.

Lo que no sabemos es el momento en que comienza a individualizarse el culto concreto a san Cecilio de los demás Varones como fundador y evangelizador de la Iglesia granadina. Tuvo que ser hacia la baja Edad Media, después que desapareciera definitivamente la comunidad mozárabe de la ciudad, hecho que se viene situando en 1162 , tras la conquista de la ciudad por 'Abd al-Mu'min, época en que la comunidad cristiana fue exterminada como tal, quedando núcleos aislados dedicados a tareas agrícolas, acostumbrados ya al menosprecio y a las humillaciones ${ }^{44}$.

En relación con este asunto existe un importante documento medieval sobre la vida de la comunidad mozárabe de la Granada en el siglo $\mathrm{X}$, el mismo siglo en que se datan algunas de las anteriores tradiciones medievales a que nos hemos referido. Resulta curioso que mientras en el norte peninsular surgen estas tradiciones sobre el origen y la idiosincrasia cristiana de la Hispania meridional, el obispo mozárabe de la Granada musulmana redacta un trascendente documento para su comunidad, de interés para el tema que nos ocupa. El documento suministra importantísimos datos y noticias sobre los mozárabes andaluces. Su redactor fue «un Obispo llamado Rabi ben Zaid, natural de Córdoba, floreció en la corte de los califas Abderrahmán III y Alhacam II: que por encargo del primero llevó a cabo varios viajes y expediciones artísticas, y que bajo la protección del segundo cultivó los estudios astronómicos y compuso varias obras de esta ciencia, entre ellas un excelente calendario astronómico-higiénico que dedicó al monarca... Cotejando las noticias que nos han quedado de este obispo mozárabe, su época, su residencia, sus estudios, aficio-

${ }^{44}$ Cfr. Arié, R., España musulmana, p. 191; Peinado Santaella, R. G. y López de Coca, J.E., Historia de Granada, T. II, La época medieval. Siglos VIII-XV, Granada, 1988, 94-100. 
nes y viajes con los de otro prelado del mismo tiempo, resulta que Rabi ben Zaid no es otro que Recemundo» ${ }^{45}$, el último obispo de la Granada musulmana del que conocemos su nombre.

Nacido en la primera mitad del siglo X, en el seno de la comunidad mozárabe de Córdoba, fue hombre sabio y culto, conocedor de las lenguas latina y árabe, cualidades que le valieron un puesto en la corte califal de ${ }^{c} \mathrm{Abd}$ al-Rahmān III donde se le conocía con el sobrenombre de $\operatorname{Rabi}^{\mathrm{c}} \mathrm{b}$. Zayd, según la costumbre de dar nombre cristiano y árabe a los mozárabes distinguidos que ejercían una función pública. En el año 955 el sultán requirió los servicios de un embajador especial para una misión difícil ante el emperador Otón I, que residía a la sazón en la lejana ciudad de Francfort y, como nadie se ofreciese, Recemundo solicitó del monarca el encargo, pidiendo anticipadamente en compensación un obispado, a lo que gustoso accedió ${ }^{\mathrm{C}} \mathrm{Abd}$ al-Raḥmān, que, como los demás califas, mantuvo este privilegio heredado de la realeza visigoda. Se le concedió la sede de Iliberri y, una vez ordenado como tal obispo, realizó satisfactoriamente la embajada, afianzando su puesto en la corte cordobesa y recibiendo siempre los parabienes del monarca, que le premió con viajes a Constantinopla y Jerusalén.

Poco o nada sabemos de su labor al frente de la sede granadina, a pesar de la referencia que hace de él el historiador Bermúdez de Pedraza ${ }^{46}$ y de los elogios sobre su religiosidad, sabiduría y prudencia del P. Flores ${ }^{47}$. Pero, por encima de todo, lo que interesa de Recemundo es su calendario astronómico y agronómico, compuesto en árabe en 961 y dedicado al califa al-Hakam II, que, como en el caso de su padre y antecesor ${ }^{c} \mathrm{Abd}$ al-Raḥmān III, estimó en mucho la presencia del sabio obispo de Iliberri en su corte.

$\mathrm{El}$ valor de este calendario es inestimable para el conocimiento de los mozárabes andaluces, al indicarnos las principales fiestas religiosas que éstos celebraban, datos éstos indispensables para conocer los centros principales de interés en las creencias religiosas del pueblo fiel. Además, se da el caso de que, estando dedicado este calendario a un sultán de religión islámica, no hace referencia a ningún día importante

\footnotetext{
45 Simonet, F.J., "Un Santoral Hispano-mozárabe del siglo X”, Ciudad de Dios, V (1871), 106.

${ }_{46}$ Cfr. Bermúdez de Pedraza, F., Historia eclesiástica, 84.

${ }^{47}$ Cfr. Flores, E., España sagrada, t. XII, Madrid, 1754, 160.
} 
en la historia y en la religión islámica, como es costumbre en los calendarios religiosos musulmanes, y mucho más estando dedicado a un califa. Por el contrario, dejó bien claro que el fin principal de su obra era esencialmente eclesial, atreviéndose incluso a conmemorar, destacar y alabar a los cristianos que habían dado firme testimonio de su fe y sufrido el martirio a manos de los musulmanes y por mandato de sus gobernantes. Este hecho nos da una idea, mejor que otros muchos documentos, de la gran personalidad y fortaleza de espíritu del obispo Recemundo. Por estas y otras muchas razones que no es el momento ni lugar de exponer, el Santoral tiene un inestimable valor para nuestra historia, en especial para la religiosa. Muestra sus vastos conocimientos de los temas cristianos de su tiempo, sobre todo referidos a la Iglesia de Córdoba. El catálogo de santos que recoge es el más extenso y completo de todos los santorales góticos y mozárabes conocidos, añadiendo al breviario común gótico de entonces muchas fiestas, que no aparecen en éste por haberse introducido en las celebraciones durante los últimos años del período visigodo e incluso ya en tiempos mozárabes. Destacan dos noticias en relación al tema en cuestión, que son la causa de que nos refiramos a esta obra y a este personaje.

En el calendario de $\operatorname{Rabi}^{-c}$ b. Zayd se incorpora ya la fiesta de los varones apostólicos el 27 de abril: «Et christiani nominant hanc diem usque ad septem, septem missos, Torquatum et socios ejus, et dicunt ipsos septem nuntios» ${ }^{48}$. Describe cómo durante siete días se celebra a siete enviados o nuncios. Se refiere, sin duda, a los siete varones apostólicos, si bien sólo nombra a «Torcuato y sus compañeros», sin hacer referencia a la iglesia concreta en que se les celebra. El que haya incorporado la fiesta de los siete no significa que se conmemoraran especialmente en cada una de las iglesias a las que fueron enviados nuncios o apóstoles. Por tanto, no nombra a Cecilio ni hace ninguna referencia a que se le tributara un especial culto en la sede que le atribuye la leyenda de los varones apostólicos, ni el referido códice de San Millán de la Cogolla. Su testimonio tiene una especial autoridad por los conocimientos que sobre las iglesias andaluzas mozárabes tiene y, sobre todo, por ser obispo titular de la sede de san Cecilio, lo que nos hace descartar cualquier tipo de culto o referencia en Granada a su supuesto primer obispo.

48 Simonet, "Un santoral", 197 
No es éste el caso del otro personaje conocido de la antigua Iglesia granadina. Así, en el mismo mes de abril, el día 24, dice: «In ipso est festum sancti Gregorii in civitate Granada» ${ }^{49}$. Frente a la ausencia del nombre y de la fiesta a san Cecilio, aparece manifiesta una celebración propia de san Gregorio en su antigua sede, de la que Recemundo era entonces obispo. Su testimonio cobra aquí especial fuerza por ser la única fiesta propia que aparece en el calendario de la iglesia de Granada, lo que significaría la estima y devoción que aún se le tenía, como primer obispo conocido que recibía culto de santo en la iglesia que rigió durante tantos años ${ }^{50}$.

Habría que esperar por tanto a las invenciones sacromontanas, inspiradas sin duda en las tradiciones medievales, para que san Cecilio adquiriera un singular culto en Granada como fundador de su Iglesia, llegando incluso a ser nombrado patrono el martes 30 de enero de 1601 , una vez que tuvo lugar la calificación de las reliquias martiriales como auténticas ${ }^{51}$. La influencia de tales hechos en la religiosidad popular fue tan grande que, a pesar de la condena oficial de la Santa Sede de los textos plúmbeos y del pergamino de la Torre Turpiana, se predicaron, escribieron e imprimieron varias vidas de san Cecilio. En este sentido es de destacar la última en ver la luz, obra que editara, en 1958, D. Zótico Royo Campos, uno de los últimos abades del Sacromonte. Su interés radica, entre otras cosas, en querer compaginar el contenido de los hallazgos con las tradiciones medievales sobre el origen del cristianismo hispano, de las que se defiende su autenticidad.

\section{Doctrina musulmana sobre la Virgen en los libros plúmbeos}

Muy diferente a Santiago y san Cecilio es el tema de la Virgen, y muy concretamente la afirmación que se hace de su Inmaculada Concepción. La Concepción de la Virgen que exponen los libros plúmbeos tiene varias fuentes de inspiración y una gran dosis de invención de tipo devocional, en consonancia con el papel de María en la reli-

49 Id., 196.

${ }^{50}$ Cfr. Martínez Medina, F.J., San Gregorio de Elvira, en Diccionario de los Santos, dirigido por C. Leonardi, A. Riccardi, G. Zarri, vol. I A-I, Madrid, 2000, 978-983.

${ }^{51}$ Cfr. Martínez Medina, F.J., San Cecilio y San Gregorio, patronos de Granada, Granada, 2001. 
giosidad popular. Pero su revelación más significativa $-\mathrm{y}$ por la que más influyó en distintos campos de la religiosidad y de la misión pastoral de la Iglesia - es su Concepción Inmaculada. Idea en la que influyen fuentes de marcado carácter islámico.

Virgen pura de pecado o no tocada por el pecado son las dos expresiones empleadas indistintamente para significar la Concepción Inmaculada de María en los libros plúmbeos. Cuando éstos son hallados, la Iglesia no se había definido oficialmente en esta materia. Las distintas escuelas universitarias y maestros en teología discutían sobre el tema y el pueblo fiel ya defendía la Concepción Inmaculada de María y buscaba por todas partes argumentos teológicos para oficializar lo que era un consenso comúnmente admitido. Desde el concilio de Basilea se pretendió definirlo como dogma universal de la Iglesia, en la sesión XVII del 17 de septiembre de 1439; pero las complejas circunstancias hicieron que aquel decreto fuera inválido ${ }^{52}$. Unos años más tarde, Sixto IV publicaría dos constituciones que supondrían una claro avance en las doctrinas inmaculistas, la "Cum praeexcelsa" del 27 de febrero de 1477, que aprobaba el oficio y la misa de la Inmaculada, y la "Grave nimis" del 4 de septiembre de 1483, en la que se exponía e implícitamente se asumía toda la doctrina elaborada pero aún no definida hasta entonces sobre esta materia.

El documento del magisterio oficial de la Iglesia más cercano al tiempo de los hallazgos fue el Concilio de Trento. De hecho, algunos esperaban de él una definición solemne de la Inmaculada como dogma de fe católica, pero no fue así. El Concilio se limitó a una referencia significativa, pero no lo suficientemente explícita ${ }^{53}$. Aparece en un apéndice a la sesión quinta dedicada al pecado original, en la que se afirma la universalidad del mismo. Si bien se declara que no es intención conciliar incluir en este decreto "a la bienaventurada e inmaculada Virgen María" 54.

52 Cfr. Pozo, S.I., C., "Culto mariano y «Definición» de la Inmaculada en el Concilio de Basilea", Scripta de María, III (1980), 609-631.

53 Cfr. Olazaran, J., "El dogma de la Inmaculada Concepción en el Concilio de Trento", Estudios Eclesiásticos, 20 (1946), 105-154.

54 "Declarat tamen haec ipsa sancta Synodus non esse suae intentionis comprehendere in hoc decreto, ubi de peccato originali agitur, beatam et immaculatam virginem Mariam, Dei genitricem; sed observandas esse constitutiones felic. record. Xisti Papae IV. sub poenis in eis constitutionibus contentis, quas innovat". Concilium Tridentinum. Diarorum, Epistularium, Tractatuum, ed. Görres Gesselschaft, v. 5, Friburgi Brisgoviae, $1911,240$. 
En este contexto podemos imaginarnos lo que significó descubrir los libros y conocer su contenido doctrinal. Cuando un importante sector de la cristiandad - en especial los Reinos hispanos con sus monarcas a la cabeza-, ponían todo su empeño en buscar argumentos para poder proclamar dogma de fe católica la Concepción Inmaculada de la Virgen, se descubren los libros plúmbeos. En ellos se revela el común sentir del colegio apostólico sobre la ausencia en María de toda mancha del pecado original o, lo que es lo mismo, decir que los apóstoles ya creían que la Virgen fue Inmaculada desde el primer instante de su Concepción. Además, y por si fuera poco, en los libros plúmbeos se decía que "esto se decretó de conformidad en el concilio de los Apóstoles como referimos en el libro de los Fundamentos de la Ley. Y quien se desconformase de él será perdido" 55.

Imposible encontrar argumentos más contundentes para justificar con toda la autoridad de la tradición apostólica la veracidad del misterio, que ya por otra parte veneraba la mayoría del pueblo fiel. Aparte de la importancia del texto concreto a que nos referimos, la relación que unos libros establecen con otros confería a su contenido una mayor credibilidad, a la vez que indicaban una elaboración y sistemática teológica. La autoridad de estos escritos era indiscutible, siempre según indicaban los mismos textos. Se autodefinían como revelados por la Virgen y el apóstol Santiago a dos de los varones apostólicos, a quienes la tradición medieval consideraba como primeros evangelizadores de la Hispania romana.

Resulta imposible comprender, desde la mentalidad y la cultura de nuestro tiempo - y después del júbilo de los hallazgos y la calificación de las reliquias-, la sorpresa y expectación desbordante que suscitó el conocimiento del contenido de los libros. Por mucho que lo intentemos nunca podremos imaginarlo. Una sociedad, y particularmente una ciudad, que se justificaba desde el espíritu de la Cristiandad, descubría que en sus orígenes había sido depositaria de tesoros tan grandes como la predicación del mismo Santiago, apóstol íntimamente vinculado a la religiosidad hispana medieval, y de sus más queridos y cercanos discípulos de los que habían aparecido sus restos; y junto a ellos unos textos escritos que se autoatribuían una autoridad similar a la de los escritos neotestamentarios.

${ }^{55}$ Libro de los actos de Nuestro Señor Jesús y de sus milagros y de su Madre, María la Virgen, Hagerty, M. J., Los libros plúmbeos, 97. 
Pero este júbilo no fue sólo de los granadinos, sino que la habilidad del Arzobispo hizo que traspasara las fronteras locales y provinciales, para hacer de la defensa de los libros y de su contenido casi una razón de Estado. Es conocida la devoción de la monarquía española por la Virgen y en especial por el misterio de su Concepción Inmaculada ${ }^{56}$. Las circunstancias hicieron que el monarca reinante en los momentos estelares de los acontecimientos generados por los hallazgos fuera uno de los Austrias que más destacó en su fervor por este misterio mariano. Y don Pedro de Castro supo aprovechar esta circunstancia:

"Apenas cumplió el Arzobispo con el decreto del Tridentino y Bula de su Santidad...; y calificó las reliquias con la solemnidad y devoción que referimos; cuando meditando en el beneficio que Dios le había hecho en la definición de tanto tesoro de reliquias y libros y descubrimiento del lugar en que primero había habitado el glorioso Patrón Santiago con sus discípulos, e intimado el Evangelio, y celebrado la primera misa en España, había tenido éxtasis maravillosos, y se le había aparecido María Santísima años antes que en Zaragoza,... impacientemente devoto del Misterio de la Purísima Concepción, cuya autoridad incontrastable había Dios puesto en sus manos; le pareció no detenerse un punto en aplicar, cuantos medios fuesen posibles, para que con tal autoridad, que era la que se echaba menos, pasase la Santa Iglesia a declararla por Misterio.

Escribió al Señor Phelipe Tercero, haciéndole cargo, de que en su tiempo se había descubierto la más segura noticia de la Concepción, tan deseada antes por la Iglesia, ya tan necesaria en tiempo, en que en las demás provincias se había controvertido; y que, pues Dios la puso en su mano en la provincia de España, era su voluntad (al parecer) manifestar la elección del Rey católico, y a los españoles para defensores de su inmunidad; y que así debía interponerse su Catholico zelo con su Santidad, que con la noticia de tan indisputable fundamento, pasase a la declaración, a que ya se había empezado a inclinar la Iglesia en el Decreto del Tridentino" ${ }^{57}$.

De esta forma nos describe en el siglo XVIII un historiador de los hechos, el inicio de esta cruzada inmaculista nacida de los hallazgos del Sacromonte y que con el tiempo se convertiría en motor de un

\footnotetext{
56 Varias son las publicaciones que se han dedicado a la defensa de la concepción Inmaculada por los reyes hispanos. Por el enfoque, por su carácter general y por la relación que establece del tema con los hallazgos del Sacromonte citamos el estudio de Stratton, S., La Inmaculada Concepción en el arte español, Madrid, 1989.

57 Serna Cantoral, D. de la, Vindicias Cathólicas Granatenses. Relación breve de las reliquias que se hallaron en la ciudad de Granada en una torre antiquisima y en las Cavernas del Monte Illipulitano y averiguaciones que cerca dello se hizieron. Lyon, $1706,90$.
} 
movimiento, que dejaría sentir su influjo en la teología, el arte, la religiosidad y en general en todos los campos que integran la cultura religiosa del Occidente cristiano. Sin duda, así se interpretó en su tiempo, al ver en estos hechos "el primer fundamento que se echó en Granada, para erigir la grande máquina de las contiendas, y triunfos de este Misterio" 58.

Si desde antiguo la devoción a este misterio mariano era una de las más comunes en los reinos hispanos, en esta época y en concreto a partir de este momento, "las controversias sobre la Inmaculada, llegaron a revestir formas de histeria colectiva" 59 , en la que participaron desde el rey hasta el vasallo, pasando por todos los estamentos y clases sociales. Sevilla pronto pasó a ser la ciudad inmaculista por antonomasia y la impulsora de este discurso, en parte porque desde el siglo XVI su Iglesia era la más importante de la Península y de América, llegando a eclipsar a la primada de Toledo.

Como en otros tantos lugares, también en estas tierras de especial tradición mariana el fervor a la Concepción Inmaculada de María era habitual, pero su arraigo y la especial fuerza que adquirió en estos tiempos se debió a la toma de posesión de la sede hispalense, el 5 de diciembre de 1610, del hasta entonces arzobispo de Granada, don Pedro de Castro, que llevó con él la polémica inmaculista. Será a partir de esta fecha cuando Sevilla destaque en la defensa del misterio.

Pero el origen $\mathrm{o}$, mejor dicho, el impulso de la contienda hay que buscarlo en las afirmaciones de los textos plúmbeos. Aquí precisamente radica su importancia. Nunca fueron aprobados por la Iglesia oficialmente sino, por el contrario, su contenido se condenó explícitamente. Pero a pesar de eso su importancia es tal, que en parte se pueden considerar como el punto de partida, el impulso inicial que llevaría a la definición del dogma de la Concepción, y de todas las controversias y demás manifestaciones culturales que caracterizaron a este tiempo y a estas tierras. Y lo que es más interesante, a diferencia de lo expuesto en relación al apóstol Santiago y a san Cecilio, en lo relativo a la Inmaculada Concepción la fuente de inspiración no son ni tradiciones medievales, ni doctrina o documentos católicos sino que en este caso es la tradición musulmana más original, las sentencias del mismo Mahoma.

58 Id., 91.

59 Domínguez Ortiz, A., "Iglesia institucional y religiosidad popular en la España barroca”, en La fiesta, la ceremonia, el rito, Granada, 1990, 9. 
Ciertamente, los dos términos que aparecen en los apócrifos granadinos para significar la Inmaculada Concepción de María no se pueden considerar del todo originales; son las expresiones empleadas en los textos sagrados islámicos al referirse al mismo tema. Ante todo hemos de recordar que la religión musulmana, por su marcado carácter sincretista, tanto en sus textos como en la práctica de los creyentes, manifestó desde sus orígenes un profundo respeto y veneración a Jesucristo y a su madre María. De manera especial se hace referencia a la infancia de ambos personajes.

En concreto y centrándonos en la Virgen María, el Islam le concede un lugar privilegiado después de su Hijo y de todos los profetas. En la teología musulmana María aparece con la dignidad de la amistad con Dios, de la santidad. Es considerada de forma especial por encima de todas las mujeres, incluso de aquellas emparentadas con el Profeta y con el Islam, y todo en razón de la acumulación gratuita de favores divinos. Los estudiosos de las tradiciones ponen en boca de Mahoma unas palabras antes de su muerte dirigidas a su hija Fátima: "Tu serás la señora de las mujeres del Paraíso, después de María" ${ }^{60}$. María es sin duda en el pensamiento del Islam la Señora, y en la experiencia religiosa de muchas de sus sectas se vive una devoción a María que llega a veces a la imitación.

Las fuentes en que se inspira no son las narraciones neotestamentarias, sino los evangelios y demás textos apócrifos, en especial los de la infancia, como el Evangelio de la Natividad de María, el Pseudo Mateo, la Historia de José el Carpintero, el Evangelio árabe de la Infancia y sobre todo el Protoevangelio de Santiago. Varios son los puntos doctrinales que se le dedican a la Virgen, unos tomados del cristianismo y otros sistematizados por el Islam; algunos, elaborados por el mismo Mahoma según cuenta la tradición. Entre estas doctrinas destaca la referente a la inmunidad del error y del pecado, por ser estos elementos esenciales entre los musulmanes, para todos aquellos personajes que como María han recibido de Dios el carisma de profecía y el de misión. Según esto, se puede decir que en algún sentido el pensamiento musulmán se adelantó a la doctrina oficial de la Iglesia católica sobre esta materia.

A la Concepción de la Virgen sin mancha de pecado original dedica la religión musulmana dos importantes textos, uno en el Corán y el

${ }^{60} \mathrm{Ibn} \mathrm{Sa} \mathrm{Ca}^{\mathrm{d}}$, Kitāb al-țabaqāt, ed. E. Sachau, II, p. 40. La cita la tomamos de J. Abd-el-Jalil, O.F.M., Cristianismo e Islam, Madrid, 1954, 92. 
otro en las sentencias del Profeta. La cita del Corán aparece en el capítulo tercero (3,33-49), que según se cree fue proclamado por primera vez en Medina hacia el 627, en vida aún del Profeta, que murió el 8 de junio del 632. El texto en su conjunto es considerado por los especialistas como la referencia más importante a Jesús y a María del Libro Sagrado de los musulmanes:

"Y cuando los ángeles dijeron: “ ¡María! Dios te ha escogido y purificado. Te ha escogido entre todas las mujeres del universo"” $(3,42)$.

Para comprender este texto hay que remontarse a unos versículos anteriores, cuando se relata la reacción de la madre de María ante el nacimiento de su hija y las palabras que pronuncia con cierta decepción ya que ella esperaba un hijo varón para dedicarlo al servicio del templo ${ }^{61}$ :

"Y cuando dio a luz a una hija, dijo: ' Señor!, lo que he dado a luz es una hembra - bien sabía Dios lo que había dado a luz - y un varón no es igual que una hembra. Le he puesto por nombre Maria y la pongo bajo tu protección contra Satanás el maldito, también a su descendencia"” $(3,36)$.

El Corán es el único en poner a María y a sus descendencia bajo la protección de Dios en contra de Satanás, idea que no aparece en los otros textos apócrifos cristianos empleados por la tradición islámica, como el Protoevangelio de Santiago o el Pseudo Mateo a los que nos hemos referido. El concepto "purificado" del 3,42 tiene un especial sentido totalizante. Algunos comentarios y notas del Corán ${ }^{62}$ ponen este texto en paralelo con Lc 1,42, al relacionar el término purificado con la exclamación de Isabel al recibir a la Virgen en su casa: "Bendita tú entre las mujeres y bendito el fruto de tu vientre". En líneas generales, la mayoría de los comentaristas de los textos sagrados musulmanes consideran "que María fue preservada de toda mancha". Al-Ālūsī resume la enseñanza corriente. Lo esencial de ella es que Dios ha purificado a María, ya sea de las manchas comunes a las mujeres (períodos, consecuencias del parto), ya de la incredulidad, dándole una fe inquebrantable, ya de la indolencia, concediéndole una virtud inalterable de

\footnotetext{
${ }^{61}$ Esta intención de la madre de María de dedicar a Dios el fruto de sus entrañas está tomada del Protoevangelio de Santiago, IV,1.

${ }^{62}$ El Corán, Herder-Barcelona, 1995, 128 (véase la nota a 3,42 de esta traducción preparada por J. Cortés).
} 
obediencia, ya, en fin, de los defectos del alma y del carácter. Lo mejor -concluye al-Ālūsī- es tomar la palabra purificación en el sentido más vasto, y admitir que Dios ha dado a María el privilegio de permanecer pura de todas las manchas en el sentido propio y en el figurado: manchas del corazón y del cuerpo; de este modo, estaba preparada para «el desbordamiento en ella del Espíritu»" ${ }^{63}$.

\section{La sentencia de Mahoma: María no fue tocada por el pecado}

A pesar de todo, hemos de afirmar que el Corán no es del todo explícito sobre el asunto en cuestión. Será en las "tradiciones" musulmanas donde aparezca explícitamente este privilegio extraordinario sólo para María y para su Hijo. En este sentido, no podemos olvidar que para un musulmán las tradiciones o hadīt tienen una autoridad doctrinal similar al Corán e incluso superior en algunos casos, por ser las enseñanzas orales de Mahoma transmitidas de boca en boca, puestas más tarde por escrito y reunidas por los comentaristas después de haber criticado su valor; es la denominada ciencia del hadit. La versión más común de esta sentencia del Profeta dice así:

\footnotetext{
"Todo hijo de Adán al nacer es tocado por Satanás, salvo el hijo de María y su madre."
}

Este hadị es considerado uno de los más importantes al ser atribuido con toda probabilidad al mismo Mahoma, por lo que aparece en los repertorios de todos los comentaristas más clásicos "entre las tradiciones más sólidas del Islam, ya que ha sido recogido en las dos recopilaciones que gozan de la máxima autoridad, la de al-Bujārī y la de Muslim. Y siempre que este privilegio de Jesús y de María ha sido atacado en cuanto a existencia o en cuanto a significación por pensadores musulmanes, los representantes de la ortodoxia la han defendido con mayor vigor" ${ }^{64}$.

La lectura de este texto guarda una íntima relación con el capítulo tercero del Corán, en el que también se habla de Satanás en relación

\footnotetext{
${ }^{63}$ Abd-el-Jalil, J., O.F.M., María y el Islam, op. cit., 30. El párrafo que hemos citado textualmente hace referencia a la obra de al-Ālūsī, Rüh al-ma ānī (Comentario al Corán), edición de El Cairo, 1927, III, 137.

${ }^{64}$ Abd-el-Jalil, J., O.F.M., María, 29.
} 
con María. Ya nos hemos referido a él como el gran texto sobre Jesús y María ${ }^{65}$, al hablar de la cita coránica que hace referencia a la concepción sin mancha de la Virgen; se dice de María que fue protegida por Dios contra Satanás el maldito, mientras que en la tradición se habla de que María no fue tocada por Satanás, frases que se interpretan como la ausencia de pecado en María. El término clave del haditu, "tocado", aparece con variantes como aguijoneado o comprimido. Aquí precisamente radica la relación, tanto en el contenido ideológico como en la forma gramatical, de este hadī con los textos inmaculistas que aparecen en los libros plúmbeos de Granada: "A María no tocó el pecado primero".

El 6 de marzo de 1682, el papa Inocencio XI firmaba el Breve "Ad circunspectam Romani Pontificis" por el que se condenaban definitivamente los libros plúmbeos y su contenido, dando así por concluido de forma oficial el largo y complejo proceso. Este documento pontificio afirmaba que los consultores, unánimemente juzgaron que "se debían prohibir y condenar los dichos Libros y todo lo contenido en las láminas de plomo, membrana o cartas referidas, porque falsamente se atribuyen a la Beatísima Virgen María, al santo apóstol Santiago el Mayor, o dictándolo él a sus discípulos Tesifón y Cecilio; antes son puras ficciones humanas fabricadas para ruina de la fe católica; y respectivamente contienen herejías y errores condenados por la Iglesia y se oponen a la letra de la Sagrada Escritura, exposición de los santos Padres y al uso de la Iglesia; demás de que muchas cosas tienen resabios de mahometismo, y parece que no inducen poco a los fieles a la secta de Mahoma, conociéndose que no poca parte de ellos está sacada o copiada de su Alcorán y de otros impurísimos libros de los mahometanos... ${ }^{6 "}$ "Concluye el Breve prohibiendo leer o retener los tratados o sus copias bajo "pena de excomunión latae sententiae", reservada su absolución solamente al Romano Pontífice.

Se prohibieron y condenaron los libros y su contenido, pero a pesar de esto su aparición fue decisiva; su influjo se dejó sentir y afectó esencialmente a importantes centros de la espiritualidad contrarreformista, y a sus correspondientes manifestaciones en la cultura y en las

${ }^{65}$ Cfr. Jomier, J., El Corán. Textos escogidos en relación con la Biblia, Estella (Navarra), 1985,61 .

${ }_{66}$ La traducción de la Bula la hemos tomado de Serna Cantoral, D. de la, op. cit., 262-264. 
artes plásticas. En este contexto, resulta de sumo interés constatar la utilización y defensa de las tesis de los libros, que hicieron significativos ideólogos "oficiales" de la Contrarreforma española; me refiero en concreto a un importante número de teólogos, que incorporaron a sus tratados, ensayos y sermones las tesis inmaculistas de los libros plúmbeos como argumentos contundentes de tradición apostólica en defensa de la Inmaculada concepción de la Virgen. Sin olvidar, lógicamente, que todas estas publicaciones tenían el "nihil obstat", que le conferían el sello de doctrina aprobada por la Iglesia católica, a pesar de la prohibición explícita del Breve pontificio. Nombres y obras como el P. Francisco Suárez y su "Quaestio theologica", los discursos teológicos del Dr. Sánchez Lucero, el Tratado sobre la Inmaculada del P. Granado, etc., la lista sería interminable, aunque no termino sin referirme a una obra significativa, La Defensa de la Inmaculada del P. Salazar, por estar dedicada a uno de los personajes más importantes de su tiempo que se caracterizó entre otras cosas por ser un defensor a ultranza de la Inmaculada Concepción, el rey Felipe III ${ }^{67}$.

\section{A modo de conclusión}

Valgan estos tres sencillos ejemplos para hacernos una idea de la riqueza y complejidad de matices que suponen el estudio conceptual de los textos plúmbeos, láminas y libros. Lógicamente, se confirman una vez más sus fuentes de inspiración en el pensamiento y doctrina del Islam. Pero reconociendo también que están muy influidos por el pasado histórico de la Iglesia y por el pensamiento y la doctrina católica, de ahí que haya que interpretarlos en este contexto. Y, sobre todo, como esperamos poder demostrar en breve, es ésta de alguna manera la tónica dominante, al estar explícitamente manifiestos los dogmas cristianos que niegan radicalmente los musulmanes. Según esto las conclusiones son patentes, lo cristiano es prioritario, y no al revés. Lo que contradice sin duda las teorías e interpretaciones del sincretismo islámico-cristiano con predominio del credo musulmán sobre el católico, teorías que incluso la condena pontificia parecía respaldar.

Una de las consecuencias de este nuevo enfoque sería la de aportar nueva luz a la visión radical y casi unilateral del problema morisco tal

\footnotetext{
67 Para este tema vease, Martínez Medina, F.J., "El Sacromonte de Granada y los discursos inmaculistas postridentinos", Archivo Teológico Granadino, 59 (1996), 5-57.
} 
y como se ha venido presentando tradicionalmente. En la línea de investigación que representan las tesis de los investigadores Francisco Márquez Villanueva y Mercedes García-Arenal ${ }^{68}$, pienso que el problema morisco debe estudiarse con otras fuentes y mecanismos de investigación interdisciplinares que nos ayuden a comprender su pluralidad, riqueza y complejidad. He indicado tan sólo algunas de estas disciplinas que precisan de una lectura más detenida, las ciencias religiosas cristianas, tan importantes e influyentes en la configuración de la sociedad española moderna. En especial, me he aproximado a la historia del cristianismo y la teología católica y su correspondiente comparación con las ciencias paralelas en la cultura musulmana. Sin éstas, creemos incompletos los estudios sobre moriscos y sobre los orígenes del Sacromonte.

En mis trabajos más recientes sobre la Historia de la Iglesia en el Reino de Granada adelanto los que considero inicios y metas del problema. En un principio "después de recibir el bautismo a comienzos del XVI, los moriscos se convierten en un poderoso grupo clandestino, que ante la hostilidad e imposición de los cristianos viejos se afianzaban en sus creencias y prácticas musulmanas" ${ }^{69}$. Pero a partir de aquí la comunidad morisca evoluciona y se fracciona, no representando en absoluto un grupo infranqueable, impermeable a todo y replegado en sí, sin dejarse influir por el contexto que le rodea. En su etapa final, ese largo siglo XVI no sería tan monolítico por una y otra parte. Así, para unos la solución estaría en la lucha armada, mientras que para otros estaría en la dialéctica y en una síntesis que buscó un difícil y casi imposible equilibrio conceptual desde los presupuestos religiosos. Y es aquí donde habría que situar el intento de las invenciones. En este sentido afirmo, en el mismo texto antes indicado, que "las doctrinas que exponían - los libros plúmbeos - a modo de enseñanzas religiosas resultaban extravagantes y de marcada intencionalidad apologética... Se insistía también en aspectos devocionales de profunda raigambre popular, con manifiestas influencias evangélicas y coránicas, que defendían complicadísimas tesis e ideas teológicas a modo

${ }^{68}$ Cfr. Márquez Villanueva, F., "El problema historiográfico de los moriscos", en $E l$ problema morisco (desde otras laderas), Madrid, 1998, 98-195; García-Arenal, M., "El problema morisco: propuestas de discusión”, Al-Qanțara, XIII (1992), 491-503.

69 Martínez Medina, F.J., "La Iglesia", en Historia del Reino de Granada. Tomo II La época morisca y la repoblación (1502-1630), Universidad de Granada, 2000, 256. 
de síntesis entre el Islam y el Cristianismo, si bien se daba cierta primacía a este credo sobre aquél, según recientes investigaciones que espero vean pronto la luz. Esta decantación por el cristianismo no suponía menosprecio del pueblo musulmán; por el contrario, entre las noticias más sorprendentes que suministraban, destaca la raza y nación árabe que se adjudica a san Cecilio" 70.

Sólo en un contexto de historia de mentalidades, donde los dos credos religiosos, cristiano e islámico, tienen gran importancia podrán comprenderse parte de los matices y el sentido profundo de los libros plúmbeos y demás escritos sacromontanos. Con todo, pienso que nunca conoceremos la quintaesencia, el significado histórico y las intenciones del grupo de moriscos y cristianos viejos que concibieron tan ambicioso proyecto.

\title{
RESUMEN
}

Lejos de ser sólo una fabulación netamente morisca en su inventores y en sus contenidos ideológicos, los libros plúmbeos tienen en su base las tradiciones medievales cristianas, la teología católica y la problemática político-religiosa de la España moderna; en su gestación también participaron activamente pensadores de marcado corte contrarreformista. En la línea actual de investigación del problema morisco, que supera la monolítica, partidista y radial visión de esta etnia, hay que iniciar nuevos campos de interpretación del contenido de los libros plúmbeos y de los hallazgos del Sacromonte granadino en general. Proponemos como ejemplo el tratamiento de personajes y temas tan fundamentales en el hilo argumental como son el apóstol Santiago, san Cecilio y la Concepción Inmaculada de la Virgen.

\begin{abstract}
The Lead Books, far from being a purely Moorish invention of its creators and in its ideological content, have at their base Medieval Christian traditions, a Catholic theology and the religious-political problems of modern Spain. In their origin, thinkers of a pronounced counter-reform view also actively participated. In the present state of research of the Morisco problem which goes beyond the monolithic, partisan vision of this ethnic group, it is essential to initiate new fields of interpretation of the books' contents and of the findings of Sacromonte in general. As an example, we suggest a treatment of the persons and themes fundamental to the thread of argument, as are the Apostle St. James, St. Cecil and the Virgin's inmaculate conception.
\end{abstract}

${ }^{70} I d ., 270$. 